\title{
MONUMENTS, CIVIL WAR AND LOCAL COMMUNITIES Archaeological Heritage in the Duhok Region (Kurdistan Region of Iraq). Part 2
}

\section{EsZTER SPÄT}

Hungarian Archaeology Vol. 8 (2019), Issue 3, pp. 36-45, https://doi.org/10.36338/ha.2019.4.6

\section{Continued from Spring 2019}

This series of articles on the archaeological heritage of the Duhok Region of Iraqi Kurdistan is a result of nearly two decades of research in the region. Though my primary research focuses on the Yezidis, an ethno-religious community, the wider cultural environment where Yezidis have to make their own space was also of some relevance. Consequently, archaeological remains, the way they are treated today and their role in the cultural imagination and historical identity-making of the inhabitants of the Kurdistan Region, whether Yezidis, Muslims or Christians, attracted my attention. The second part of my work looks at four little-known sites in the governorate of Duhok and at locals' interest in them (or the lack thereof.)

\section{GEVERKE ASSYRIAN RELIEFS}

Also known as Maltai Reliefs and Halamata Caves, the Geverke Reliefs are three panels showing the king Sennacherib facing a procession of Assyrian gods depicted in human forms and mounted on animals. (Some online descriptions talk about four panels, but the fourth panel is located some distance away.) The panels are cut 200 meters high into the rocky side of the Zawa Mountain, just above the river Duhok and the village of Geverke. The old town of Maltai, with an ancient tell rising in its middle is just opposite the reliefs, over the plain. ${ }^{1}$ There is no road leading to the reliefs, one has to climb the steep and rocky mountain side or take the road running on top of Zawa Mountain — a much favored picnicking spot—and try to find their way down from there.

The reliefs were carved in the 7th century B.C. during the reign of the Assyrian king Sennacherib. According to a description of the engravings on the website of an exhibition at the Metropolitan Museum of Art: "The iconography and location of this group of reliefs are of particular interest. Unlike other examples of Assyrian royal art, in which the king is represented worshipping symbols of gods, these reliefs show the king gesturing in front of anthropomorphic deities, or gods in human form. They depict a relatively small figure of the king as a worshipper facing right toward a line of five large gods and two goddesses mounted on animals and fantastic beasts, including from right to left, the gods Ashur, Ninlil, Sin, Anu or Enlil, Shamash, Adad, and Ishtar" (MALko, 2014). A cave was carved into one of the panels, just like into the central relief in Khinnis, in all probability by Christian monks (Fig. 1).

Hardly anybody had heard of the Assyrian engravings of Geverke among the inhabitants of Duhok before 2003, when miles of cultivated orchards and empty fields separated Duhok from the village of Geverke, and the guidance of local village boys was needed to find the engravings. Cut into the rocks high up on the mountain, the engravings are nearly invisible to the naked eye from down the road. I was first told about the reliefs by a colleague

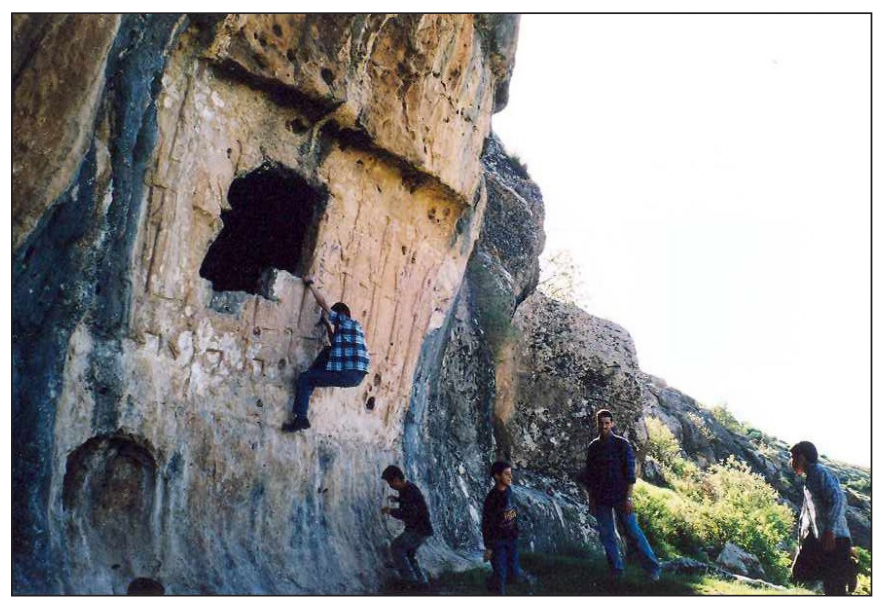

Fig. 1. Boys climbing into a cave carved into the Assyrian reliefs of Geverke (2003)

Exact location: 36 50’24.14” N, 42 56’ 42.62” E (Falk-Dulz, s.a.) 


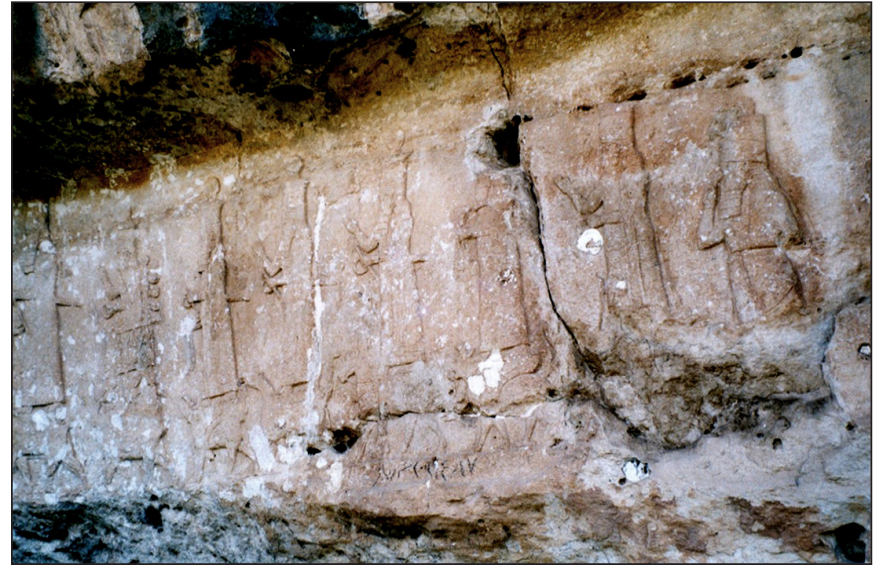

Fig. 2. A view of Geverke in 2003; damage from weathering is obvious at the University of Duhok. He, however, wasn't sure where they were located and advised me to make enquiries at the Duhok Directorate of Antiquities. The reliefs were also mentioned by a Yezidi intellectual from the Yezidi Lalish Cultural Center (who eventually became one of the political leaders of the community). For him, the Assyrian reliefs were a proof of the ancient nature of Yezidi religion and its close relation to the ancient civilizations of Mesopotamia. While not denying the Assyrian origins of the engravings, he insisted that the reliefs represented the Seven Great Angels of the Yezidis (SРÄт, 2008, p. 401). In reality, there are nine figures in each panel, seven gods, with a king facing them and a king following them (Fig. 2).

In the years of Kurdish economic boom following the fall of the Saddam Regime, the size of Duhok quadrupled. The village of Geverke, as well as Malta, came to be incorporated into the town of Duhok, and the Assyrian rock engravings attracted more local attention. This was also due to the rise of "official" interest in the ancient heritage of Kurdistan, as in their attempt at creating a Kurdish state, the authorities strove to project the image of Kurdistan as the "cradle of civilization." These are the exact words written on a huge sign greeting visitors on the rock wall of the gorge leading to the Duhok Lake, a popular recreational spot. The sign is just next to the ancient stairs carved into the rock face and leading up to a series of artificial caves. In 2002-2003, during my first stay in Duhok, these caves were only visited by teenagers with nothing better to do. Then the biggest cave, accessible only through a tunnel carved into the rock and named "Four Pillars Cave" on account of a large altar in its center connected to the ceiling by four thick pillars, was declared a Zoroastrian temple and further excavations were carried out, accompanied by much Kurdish media interest (FolTz, 2017, pp. 102-103). All this has helped to raise interest in ancient monuments among Duhokis, which has also had a negative side-effect. While today the Four Pillar cave complex can only be visited after buying a ticket, the Geverke caves still stand unguarded, their only protection being the steep hike up the mountain side. This has not proved enough, however, against vandals and looters. Graffiti first appeared on the engravings around 2008 (as reported by an American colleague teaching at the American University of Kurdistan in Erbil; DailyHaWler, 2008). It must be noted, that graffiti as such is also a new development in Duhok, imported after 2003. Though attempts were made to wash off the graffiti, remains of it can still be seen and further graffiti followed (Fig. 3). In 2016 a great outrage was caused in the transnational Assyrian (Neo-Aramaic-speaking Christian) diaspora, when a Kurdish flag was spray-painted under the reliefs. This act was seen by the Assyrians, who

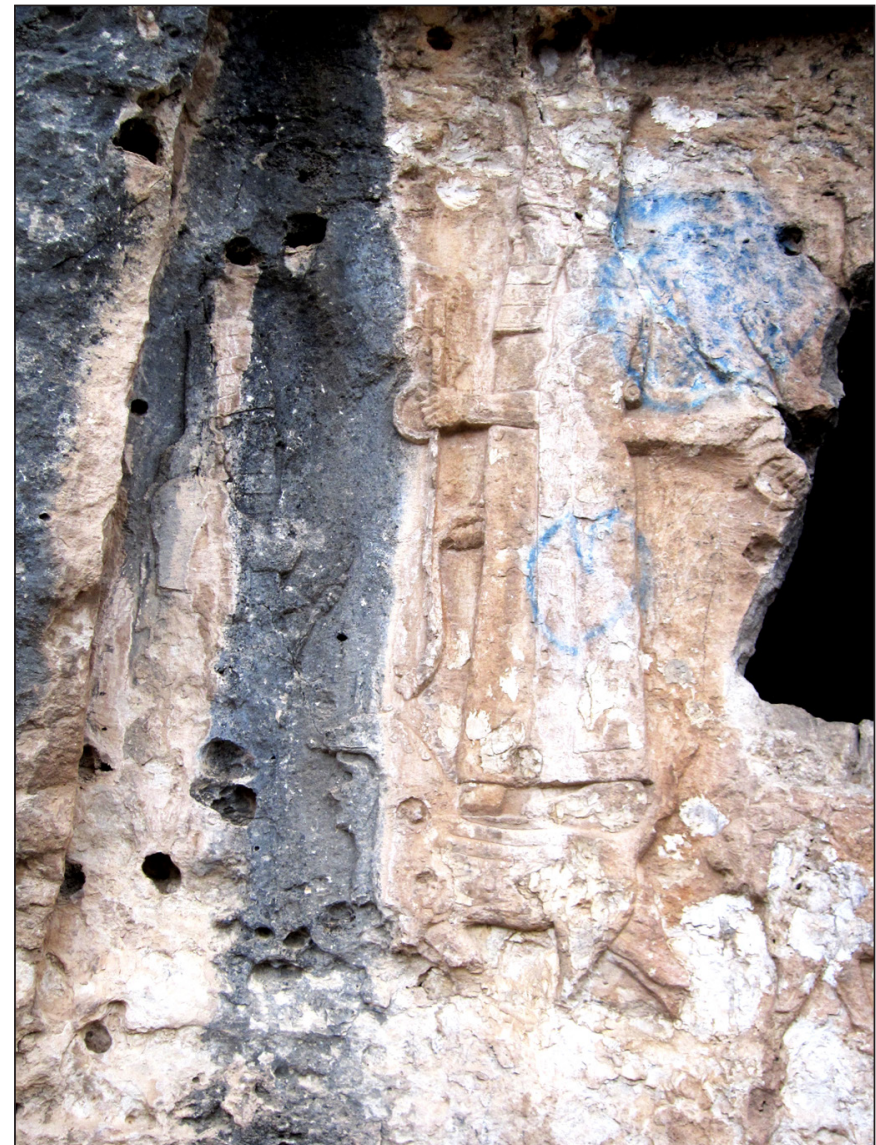

Fig. 3. Detail of the Assyrian relief; the damage by weathering and graffiti is clearly visible 
consider themselves as the direct descendants of the ancient Assyrians, as a Kurdish nationalist attack on the Assyrian national heritage and identity, rather than mere vandalism. (A huge chunk was already missing from one of the panels when Gertrude Bell visited in 1909; Bell, 1909; photos M054-M057). ${ }^{2}$ The flag has since been removed. However, vandals, or rather art-looters, have caused more irrevocable damage: on the 6th of March, 2018, the Kurdish online news site, Rudaw English reported that the site had been damaged by theft (ALI, 2018). Though the article is not quite clear, claiming that someone "stole some pieces from the cave," the attached pictures make it clear that a huge chunk (of one of the Assyrian gods) had simply been gouged out from one of the reliefs.

\section{PIROMARA CITADEL}

Piromara Citadel is the name given (probably by expats living in Duhok) to the ruins of an unidentified fortification on a peak of the Duhok Mountain above the town. ${ }^{3}$ Once again, the majority of locals (even those living right under it in the newly built suburbs of Duhok) have never heard of the citadel or even of the name Piromara. Some expats, for whom it is a favourite weekend hike destination (if they do not possess their own transport to leave the town on weekends), refer to as it Piromara Citadel, but most of them call this tour "the cemetery walk," as they usually start their hike next to a huge cemetery on the lower slope of the mountain, or "farm walk," as the hike ends in a farm, back down in the valley. Reaching the peak, one is treated to beautiful views of the Tigris and the Niniveh (or Mosul) Plains on the south-eastern side, and of the Duhok Lake (an artificial water reservoir created in a valley when the Duhok Dam was constructed by Saddam) and rows of mountain ranges in the distance on the north-western side. It takes some familiarity with the terrain to choose the right tracks and scale the right passes in order to reach the peak. Those who know their way and take the right tracks along the rocky ledges and reach the "right" peak, can explore the ruins of some ancient fortification (or as the expats call it, "the citadel"). The remains of stone walls can be detected in several places and there are room-like, artificially carved caves, as well as a narrow tunnel leading to the other side of the peak, carved into the rock (Fig. 4). Walking on the small plateau just below the peak, one has to be careful not to fall into any of the surprisingly deep water cistern hiding in the grass.

It is worth noting that other nearby peaks have more recent stone walls. These served as the outposts of the Peshmerga, or Kurdish soldiers ("those who face death"), between 1991 and 2003. During these years the Peshmerga, no longer mountain guerillas, but salaried members of the official army of a quasi-independent Kurdish Region, were constantly watching out from the mountain tops above Duhok for any possible military invasion by the Iraqi army from the direction of the Niniveh Plains. At present, these outposts are abandoned, as Kurds have pushed their de facto borders more to the south.

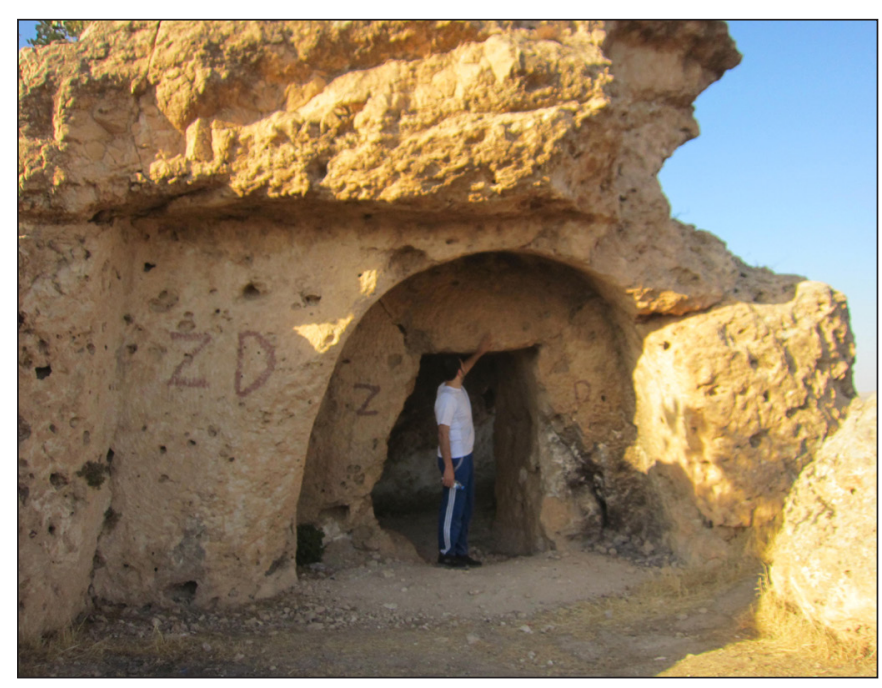

Fig. 4. Narrow tunnel in the Piromara Citadel

\section{QALE(T) BADRE: CASTLE OF BADRE}

Qale Badre (Castle of Badre) is the name given to the mysterious ruins of a castle above the former Yezidi village of Badre (Fig. 5). It can also be reached from Duhok, if one scales the steep slopes of the Zawa mountain range rising above the town (finding a path leading to the plateau is not easy, as the last ascent

\footnotetext{
2 Several Twitter messages were posted in connection with this vandalism under the hashtag \#savassyrianheritage. See also: IshtarTV, 2016; Conflict AntiQuities, 2016. Several online articles mistakenly referred to the site as Khinnis.

33653 ' 10.21" N, 42 58' 46.37” E (Falk-Dulz, s.a.)
} 


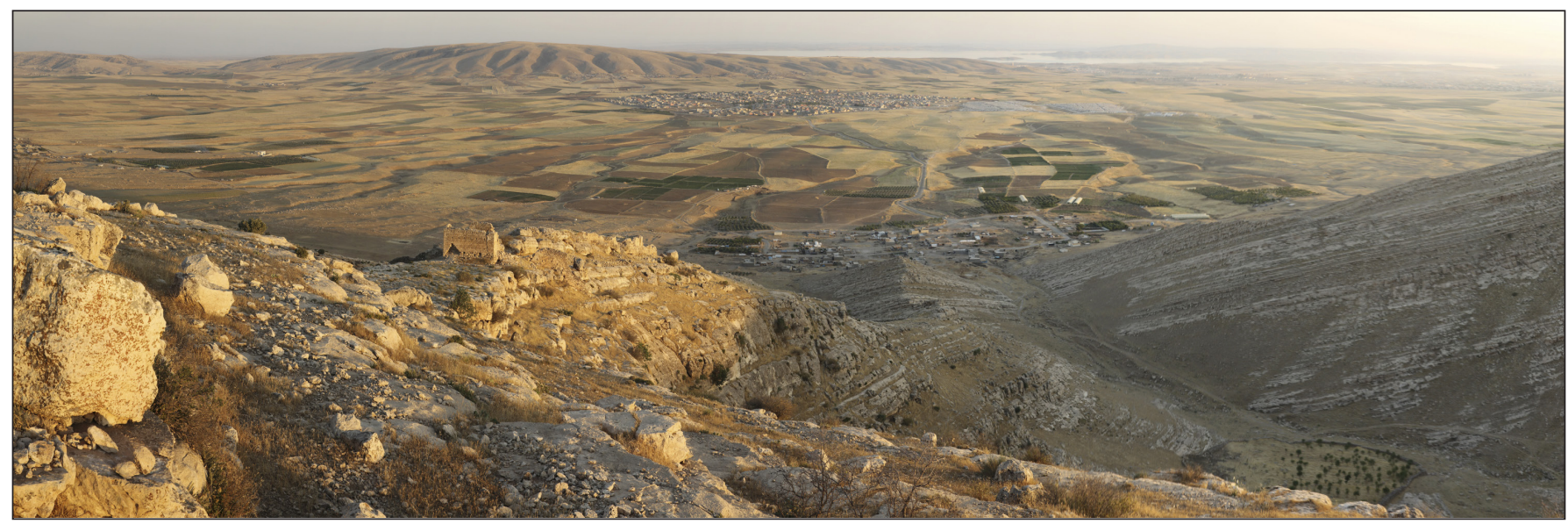

Fig. 5. Qalet Badre (photo courtesy of Noe Falk)

to the top mostly consist of sheer cliffs) and then descends on the other side. ${ }^{4}$ A number of Yezidi villages used to lie at the foot of the Zawa mountain on the southern side, before Saddam destroyed them in the mid1980s. The castle (though "fortification" may be a better term in this case) appears too small to have housed the dwelling quarters of a noble family and seems to have served solely military purposes. Midway up the rocky mountain side, it offers spectacular views of the valley bellow (followed to the south by another mountain range, which served as the border between Arab Iraq and the Kurdistan Region between 1991 and 2001) and of the Tigris to the east. The castle was built on a steep hillside towering above a wide valley, on a narrow mountain ridge, and is bordered by cliffs on two sides, while an artificial ditch carved into the rock separates it from the sloping hillside. This ditch cuts the mountain ridge, and stones quarried from here were used to build the castle. This is the only side where the fortification could be attacked; on the other sides, a wall — mostly destroyed by nowprotected the irregular triangle-shaped, sloping plateau on which the castle was built. There are narrow loopholes in some parts of the wall, and the different building periods are discernible at corners and adjoining wall segments. Some of the stone rows are set in white mortar, while dry walling was applied when building other wall sections, especially on the top. The tower-like building serves as a protection on the inner side of the ditch; its still standing walls are the most spectacular elements among the ruins. The lowermost part of the building consists of huge ashlars, and the size of the building stones decreases from the bottom to the top. On the side facing the ditch there are loopholes and the traces of a cornice are visible; in all probability these represent different construction phases. Today, a wall segment that has crumbled down is used as an entrance, but originally there was a gate building on the right-hand side of the tower. The original entrance of the tower itself opened to the courtyard; its gate is well pre-

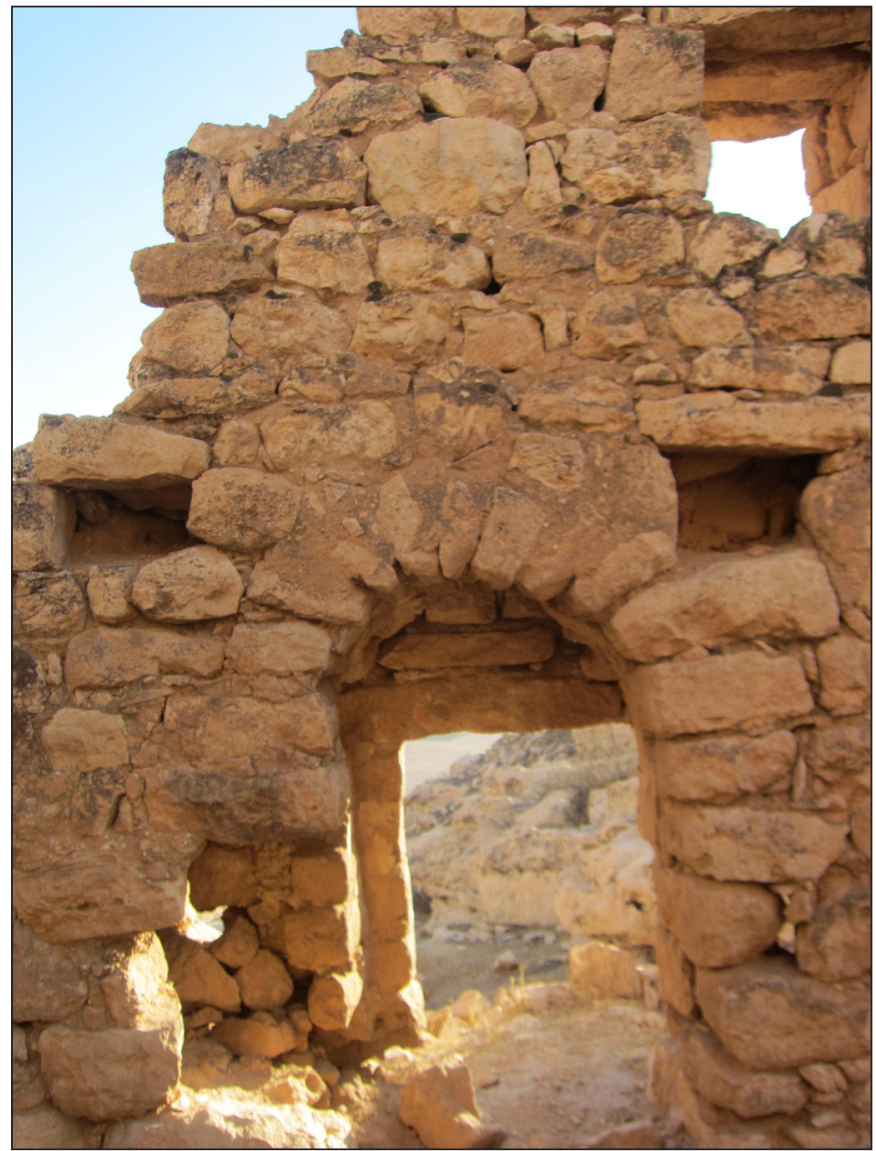

Fig. 6. The original entrance to the tower of Badre castle 
served, built of large stones and forming a rectangular shape on the outside and an arch in the inside (Fig. 6). Above this entrance, the spaces accommodating the beams covering the ground floor room, and the rectangular windows that opened to the courtyard are still visible in the wall. On the side facing the ditch, however, only the narrow rectangular loopholes are seen above the adjoining points of the beams. This massive tower first and foremost served protective purposes, fortifying the complex from the side where attacks were expected; however, its huge internal space made it suitable for residential purposes as well. There are ruins of other tower-like building parts inside the ditch, closer to the cliff, testifying to several construction periods

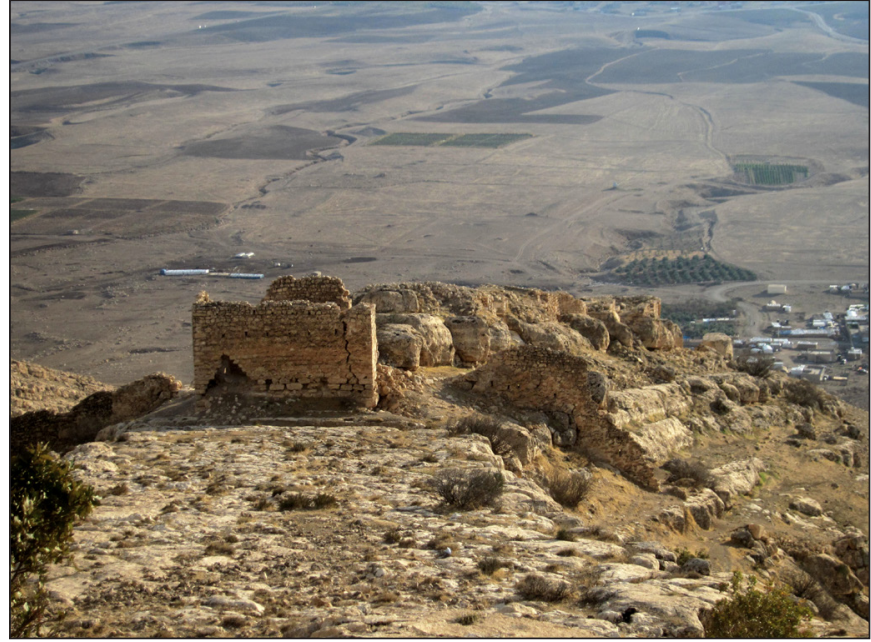

Fig. 7. Badre castle viewed from a mountain top and different building materials. Traces of round cisterns that widen from the top to the bottom are seen carved into the sloping plateau encircled by the protecting wall; however, there appear to be no internal walls, implying a lack of living quarters (Fig. 7). ${ }^{5}$

The castle does not seem to attract any visitors - a fact attested by the complete lack of plastic bottles, chocolate wrappers and similar litter. The inhabitants of Duhok (not given to climbing mountains) do not have any knowledge of the castle whatsoever. Yezidis living in the collective town of Shariya on the plain facing the mountain and the castle are aware of its existence, but can only say that it "is very old", at least "three and a half thousand years old," with some claiming that it was built by Christians. There used to be a small Yezidi village named Qale Badre right under the castle, just at the foot of the mountain, taking its name from the castle above. Its (former) Yezidi inhabitants, however, lay no claim to the castle. The most detailed information on the past of Qale Badre came from an elderly lady (probably born around 1940), who belonged to the priestly family of the pirs of Khatib Pisi (a Yezidi holy being, the "protector" of the inhabitants of the village). According to her, the pîrs of Khatib Pisi and their "followers" (murids) belong to the Basi tribe, which used to live in what is today Turkey, near to the town of Batman. In 1916 their village was attacked along with those of their Armenian neighbours. While the genocidal events in the Ottoman Empire during the First World War are known to the West as the "Armenian Genocide" and the primary targets were indeed Armenians, other non-Muslim groups, including Yezidis, Syriac Christians (mostly from the Tur Abdin plains) and the "Assyrian" Christians of Hakkari mountains, also became victims. Some of the Yezidis as well as Christians fled to what is today Northern Iraq (Iraqi Kurdistan Region and Sinjar) for refuge. Perhaps because they had no Armenian population, these regions were less affected by the genocide. Regarding the Basi tribe, my informant claimed that of three hundred and three people of the tribe only thirty-five (thirty men and five women) had survived and reached the safety of Northern Iraq after a forty-day track. First, like many other refugees over the years, they went to seek refuge from the Mîr (Prince) of the Yezidis and looked for livelihood in his village, but after a few years they (or at least some of them) moved to Qale Badre to work as shepherds (a typical Yezidi occupation in the past). According to the pir, at the time Qale Badre, though also housing Christians, belonged to a rich Arab family she referred to as "begs." When later on the "begs" moved to Baghdad (where the family is said to still live), they sold the lands to the newcomers and Qale Badre became a Yezidi village. The Yezidis of the Basi tribe continued to live in the village of Qale Badre until the second half of the 1980s, when Qale Badre, along with other Yezidi villages around the valley, was destroyed and its inhabitants were moved into a mujamaat, or collective town called Shariya out on the open plain. This "collectivization" was designed to facilitate the government's control over the population and curtail their support for the Peshmerga, the Kurdish guerrillas of the mountains. It

I am grateful to József Laszlovszky’s contributions to the castle’s archaeological description, based on the photos. 
was not restricted to Yezidis, but affected all of Northern Iraq in the course of the 1980s and '70s, reshaping the settlement pattern as well as the economic, social and cultural life of the whole region. After 2003, during the years of unprecedented economic growth, the Kurdistan Regional Government gave financial support to the inhabitants of mujamaats to rebuild their old villages. This was part of a program that aimed at encouraging people to return to their villages, both in order to strengthen agricultural production-Kurdistan relies mostly on imported food despite its fertile soil-and to revive village life, which constitutes and important element of the nationalist image of "genuine Kurdish culture." Most of the villagers had no intention of leaving the collective town (which offered far more modern amenities than small villages), but they saw no point in refusing the free money. Furthermore, they found it a good strategy to build houses, as lands with houses on it cannot be expropriated by the state. Fears of land expropriation were raised by rumours that the Kurdish government was going to construct a tunnel through Zawa mountain connecting Duhok with the valley, and that it was planning to build new settlements in the valley in order provide housing for the fast growing population of Duhok. People worried that their lands may be appropriated by the Kurdish state to accommodate the new settlements or roads. However, as the state-donated money was not enough to complete the houses, these were left half-finished, with only a few shepherd families (Arabs and Sinjari Yezidis) living in them. After the 2014 ISIS attacks on the Sinjar region, Sinjari Yezidi refugees moved into the half-finished houses or into small mud-brick houses and tents drawn up next to them. As years after the final collapse of ISIS in Iraq most refugees still have no hope of returning to their destroyed homes in Sinjar, it is likely that Sinjari refugees will make Qale Badre, named after the mysterious castle above, their permanent home.

\section{AKRE - A HIDDEN HERITAGE TOWN}

Climbing the steep slopes of a mountain range a hundred kilometres east of Duhok, the town of Akre (Aqrah) has much to offer in the way of both tangible and intangible heritage. Despite this, the outside world does not seem to know about this town, while the inhabitants of Kurdistan seem to care little. It is not even on the "must see" list of the Kurdistani expat community. (Travelers must also make sure that they specify "old" Akre to their taxi drivers, if they do not want to end up in new Akre, down on the plains.) Situated in the territory of the Zibari tribe, in the past Akre was a town with a mixed population of Muslims, Jews and Christians, with strong ties between the three communities. Jews were forced to leave in 1951. The Christian community has been fast dwindling for decades. Christians first left for the urban centres, seeking new professional opportunities, while in the nearly two decades that followed the fall of the Saddam regime many have left for the West. It is not clear how many Christians there remain in Akre, but these days it is seen as a conservative Muslim town.

\section{The Old Town}

The scenic old town of Akre, built on the slope of a mountain, with its old houses constructed of yellow stone is one of the very few examples of architectural heritage that has survived Saddam's attacks on Kurdistan and the rapid modernization driven by the affluence of post-Saddam years (Fig. 8). As Kurdish society follows the philosophy of "the newer the better," it is doubtful how long the old town will survive. As it is, some of the old stone houses are falling (or have already fallen) down, others have been replaced with more modern ones (Fig. 9). The winter of 2018-19 has proved especially taxing on the built heritage of the town. The exceptionally heavy winter years destroyed many of the town's ancient houses. Locals then proceeded to rebuild their homes "using stones from collapsed houses," though efforts are made by some to retain the traditional architectural style. ${ }^{6}$ Above the houses stands a Christian church still in good condition, however it appears to be permanently locked and none of the passers-by seemed to know how it was possible to get in and even if it was still functioning at all.

6 https://www.rudaw.net/english/culture/02082019 


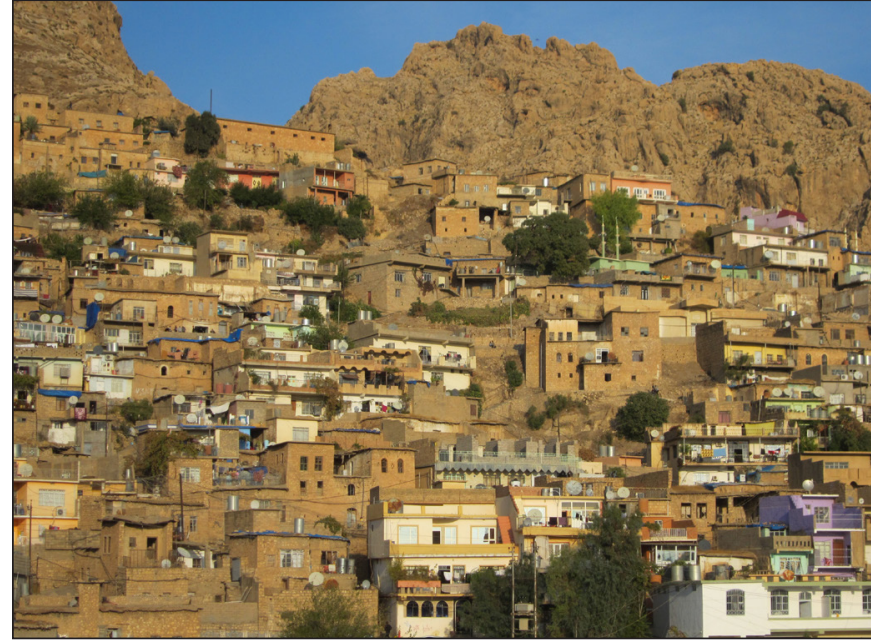

Fig. 8. Old houses built of yellow stone in the Old Town of Akre

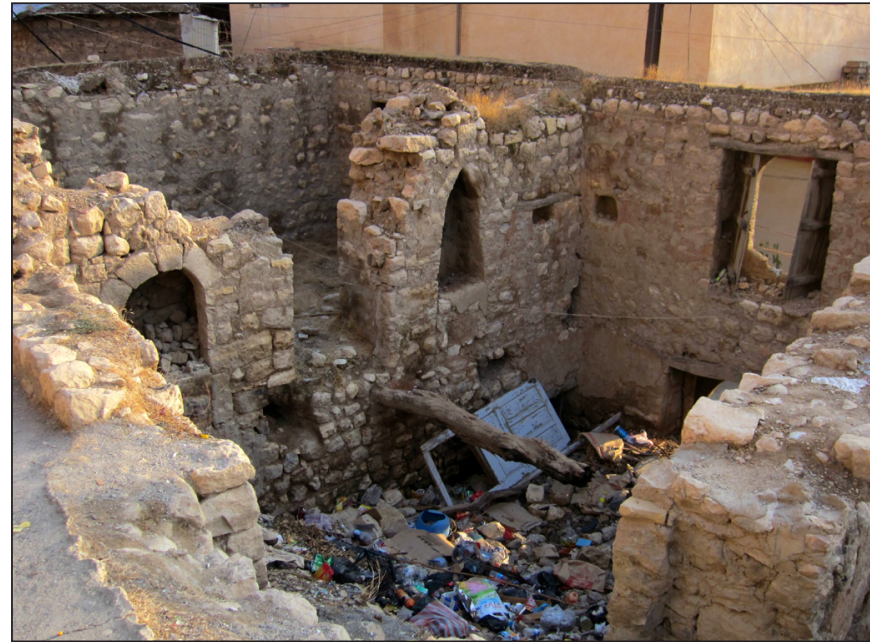

Fig. 9. Abandoned old building in the Old Town of Akre, with a newly erected building in the background

\section{The QAdri Teqiye}

Near the old town, at the mouth of a mountain gorge, stands the last functioning teqiye (dervish lodge) of the Duhok-governorate. Sufism, or the mystical movement of Islam has practically disappeared in the past few decades from this northern region, as a result of the socio-economic and cultural transformations. However, the Akre teqiye, which belongs to the Qadri Sufi dervish order, still attracts followers, albeit primarily from the villages lying to the south.

The teqiye buildings are brand new and unimaginative, offering little of aesthetic interest despite the scenic location. However, the teqiye itself is of immense importance when it comes to the fast disappearing religio-cultural heritage of the region. The teqiye is built around the tomb of the Sufi saint Abdul Aziz Gilani, son of Abdul Qadir Gilani, the 12th-century founder of the Qadri order, a wide-spread branch (or rather path) of mystical Islam. The tomb makes the Akre teqiye an important centre of pilgrimage and ritual life. The sheikh family, hereditary guardians of the tomb, live in the teqiye and take care of the tomb and of pilgrims. Some of the latter come merely to pray at the tomb and to ask for the intercession of the saint (and of the sheikh) to help with their troubles. Others come to participate in the Sufi ritual or mawlids. (Mawlid literally means "birthday" and originally it referred to the birthday of the Prophet, celebrated with rituals that included special readings, and in some places music and dancing, that is, the semah ritual as well. Eventually in some locations, like in Akre and its environs, mawlid came to designate all communal Sufi rituals, not only the birthday of the Prophet.) These mawlids feature prayers, as well as music accompanied by ecstatic dancing, sometimes leading to a state of altered consciousness and spectacular feast of self-mortification. The teqiye functions as the ritual centre of the region, attracting dervishes (or followers of the order and of the Akre sheikh) of both genders from the villages to the south of Akre. The teqiye is also visited by Iranian Kurds (allegedly both Sunni and Shia) and even Arabs from Mosul and as far as Baghdad, especially on holy days when buses bring pilgrims from far-away places to participate in the ecstatic ritual dance. Interestingly, the teqiye was said to have no dervish followers among the townspeople of Akre itself. Akre people only come to visit on holidays to express their good wishes to the sheikh family as a form of courtesy, or to ask for supernatural intercession from Abdul Aziz Gilani, the Sufi saint buried at the teqiye, in case of sicknesses. ${ }^{7}$

Some young Akre people even expressed their amazement upon hearing that I had visited the Akre to see the ritual. They failed to see what interest it could have for anybody but old villagers, demonstrating that this form of intangible heritage no longer seems interesting for the Kurdish middle class. 
Eszter Spät • Monuments, Civil War and Local Communities

Akre Castle

Above the town, on top of the mountain are the remains of a mysterious fortification-mysterious, because nobody seems to know who built it and when. Katalin Czellár, a Hungarian historian of architecture, writes in her guidebook that it used to be a famous Kurdish fortress, but she gives no further information (CzELLÁR 1979, p. 282). According to the official website of the Board of Tourism of Kurdistan, it was built by a Prince Zand in 580 BC. Some put forward the not very convincing claim that this was a small hilltop

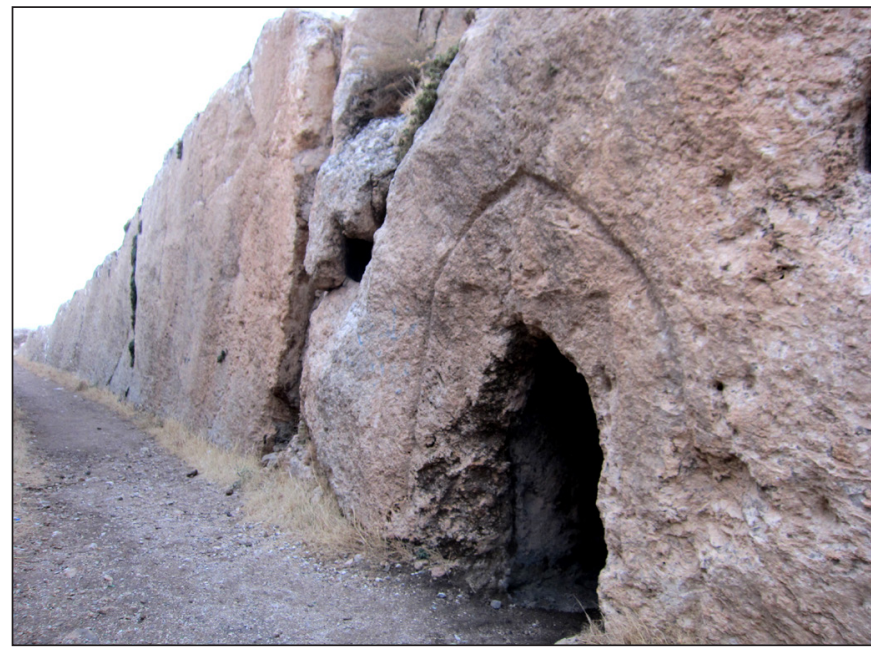

Fig. 10. Entrance of a room carved into the rock in Akre Castle

monastic settlement. ${ }^{8}$ According to the most reliable source I could find, a group of Polish archaeologists who were working on a nearby ancient dig, "nobody really knows." It is certainly different from our usual idea of a mountain-top castle. Instead of the usual walls, most of what remains is carved into the rock-body of the mountain. The visitors can see rooms as well as what appears to have been water channels cut out of solid rock, and a road (beside the requisite caves, complete with doors and windows, carved into the side of the mountain, Figs. 10-11). A straight ditch carved into the rock runs all the way down from the top of the mountain and up the side of another mountain, where it ends right next to a hole or cave opening in the rock wall. It may have once carried spring water to the castle in a feast of engineering, but this interpretation is possible only if there was a closed system of pipes running in the canal, in which water was carried from the high mountain side to the lower lying building. The most interesting feature of the castle is a cave complex, which is not easy to find (and if it had not been for a small group of teenagers who were happy to see foreigners and offered to show it, we would have never found it ourselves). It can be accessed over

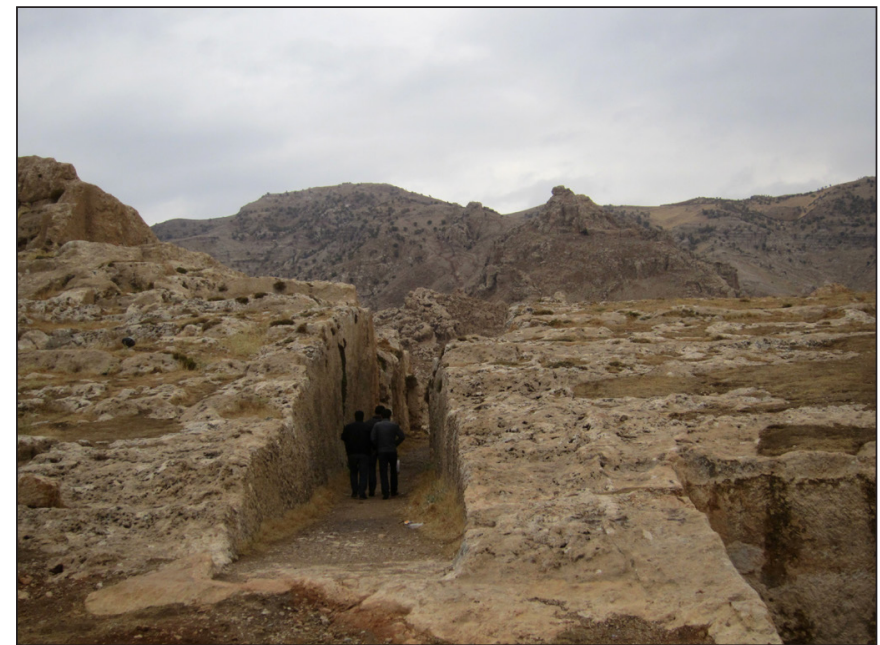

Fig. 11. A straight road carved into the rock, running down the hillside from Akre Castle

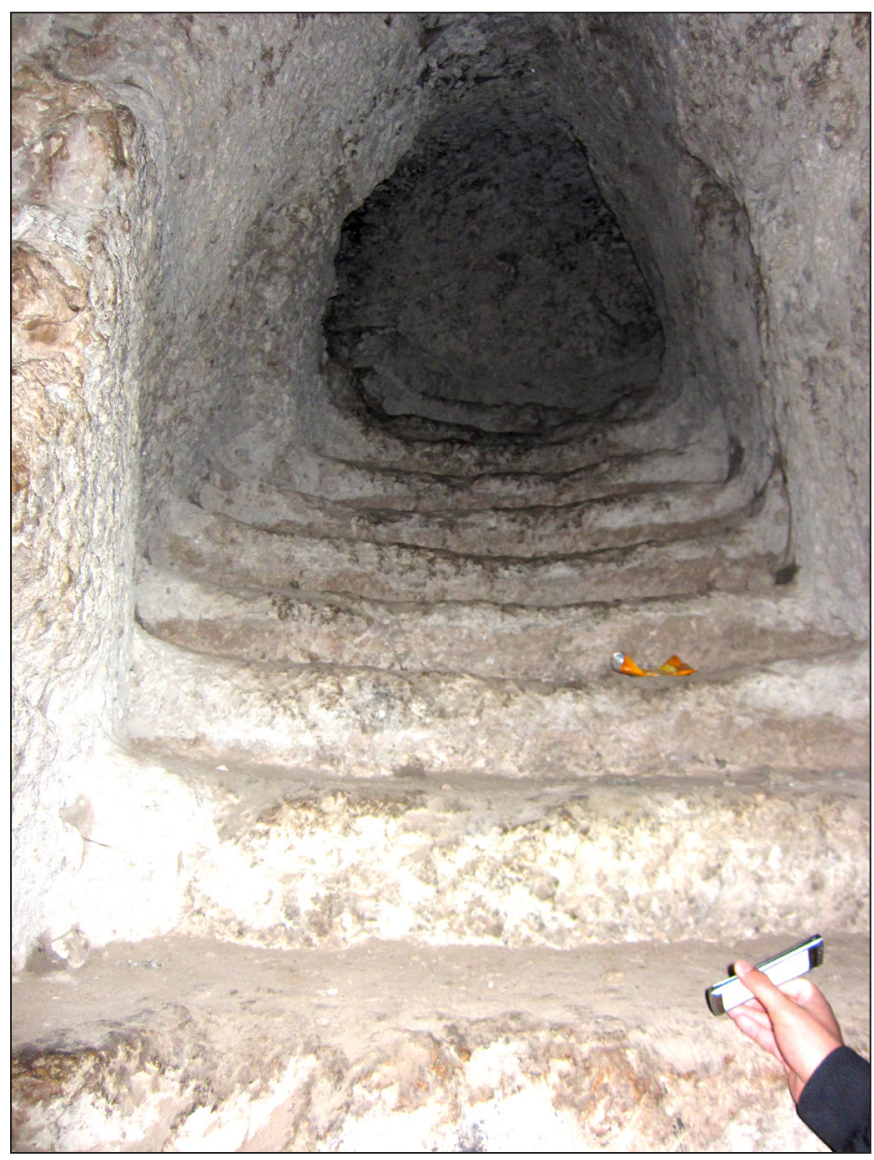

Fig. 12. A tunnel with steep steps carved into the rock in Akre Castle 
the top of the mountain and a short way down the other side, past stone "chimneys" opening up under our feet, letting light into the huge artificial cave carved into the mountainside. The cave was accessible through a small stone portal, but inside it opened into a wide tunnel. At the end of the tunnel, steep steps precisely carved into the rocky wall of the cave led up toward yet another, very narrow tunnel (Fig. 12). According to the young men who claimed to have explored it, the tunnel becomes wider as it passes through the mountain, leading to three underground chambers.

The castle is today a favourite meeting place of local teenage boys in this conservative town, famous for its lack of anything to do. Young man like to idle around here, free from the observing eyes of their elders, and make a picnic - with soft, or in some cases not-so soft drinks, and leaving a lot of garbage around, of course. The most important "historical" function of Akre Castle these days has little to do with the mysterious past of the fortification. On the 21st of March - when Newroz, the New Year, considered a symbol of Kurdish struggle for freedom in modern Kurdish nationalist mythology, is celebrated - a huge Kurdish flag (red-white-green with a yellow sun disc in the middle) is hung from the side of the mountain. As dusk descends, people carrying lit torches climb the path leading to the castle in a procession. ${ }^{9}$ The event attracts an ever growing number of young people (of both genders) with nationalist sentiments from all over Kurdistan.

\section{BIBLIOGRAPHY}

Ali, N., 2018.

Thieves raid 2700-year-old site in Duhok. [Online.]

Source: https://www.rudaw.net/english/kurdistan/050320186 [Last accessed: September 30, 2018.]

BELL, G., 1909.

Malthai. Photographs. Gertrud Bell Archive, Album M, 1909, Iraq, Turkey: photos M054-M057. Source: http://gertrudebell.ncl.ac.uk/ [Last accessed: September 30, 2018.]

Conflict Antiquities, 2016.

Maltai, Dohuk, KRG, Iraq: Peshmerga have not used ancient Assyrian art for target practice. Blog post, February 23, 2016. [Online.] Source: https://conflictantiquities.wordpress.com/2016/02/23/iraq-krg-dohukmaltai-peshmerga-destruction-false-claims/

Czellár, K., 1979.

Irak. Budapest: Panoráma.

DAILYHAWLER, 2008.

Halamata. Blog post, May 11, 2008. [Online.] Source: http://dailyhawler.blogspot.com/2008/05/halamata. html [Last accessed: September 30, 2018.]

FALK, N. \& Dulz, I. [n.d.]

Hikes in Kurdistan. Unpublished manuscript.

FolTz, R., 2017.

The 'Original' Kurdish Religion? Kurdish Nationalism and the False Conflation of the Yezidi and Zoroastrian Tradition. Journal of Persianate Studies 10(1), pp. 87-106.

9 For a video of the event see the BBC article: $h$ ttp://cabinet.gov.krd/a/d.aspx? $1=12 \& \mathrm{~s}=02010200 \& \mathrm{r}=73 \& \mathrm{a}=34306 \& \mathrm{~s}=010000$; for more photos, see https://www.google.hu/search?q=akra+kurdistan\&tbm=isch\&tbo=u\&source=univ\&sa=X\&ved=2ahUK EwiD3ND2497dAhWNJlAKHRf9D0kQsAR6BAgFEAE\&biw=1366\&bih=613\#imgrc=XSH0-gZQfzjRsM 
Eszter Spät • Monuments, Civil War and Local Communities

ISHTARTV, 2016.

Kurdish Flag Spray-painted on 7th Century BC Assyrian Relief. February 23, 2016. [Online.] Source: https://www.ishtartv.com/en/viewarticle,37843.html [Last accessed: September 30, 2018.]

MaLKo, H. 2014.

Neo-Assyrian Rock Reliefs: Ideology and Landscapes of an Empire. [Online.] Source: https://www. metmuseum.org/exhibitions/listings/2014/assyria-to-iberia/blog/posts/rock-reliefs. [Last accessed: September 30, 2018.]

SPÄT, E., 2008.

Religious oral tradition and literacy among the Yezidis of Iraq. Anthropos 103(2), pp. 393-403. 